\title{
Dromedary milk fat: thermal and structural properties 2. Influence of cooling rate
}

\author{
Nadia KARRAYa, Christelle LOPEZ ${ }^{\mathrm{b}}$, Pierre LESIEUR ${ }^{\mathrm{c}, \mathrm{d}}$, Michel OLLIVON** \\ a Unité d'Analyse Alimentaire, ENIS, BPW 3038 Sfax, Tunisie \\ b UMR 1253 Science et Technologie du Lait et de l'CEuf, Inra-Agrocampus Rennes, \\ 65 rue de Saint-Brieuc, 35042 Rennes Cedex, France \\ c LURE, Université Paris Sud, Bâtiment 209D, 91405 Orsay Cedex, France \\ d UMR Physico-Chimie des Colloïdes, Université Henri Poincaré, BP 239, \\ 54506 Vandouvre-lès-Nancy, France \\ e UMR 8612 du CNRS-Université Paris Sud, Équipe Physico-Chimie des Systèmes Polyphasés, \\ 5 rue Jean-Baptiste Clément, 92296 Châtenay-Malabry, France
}

Received 17 February 2005 - Accepted 29 March 2005

Published online 1 October 2005

\begin{abstract}
The crystallization behavior of anhydrous dromedary milk fat (ADMF) was examined using Microcalix (Centre National de la Recherche Scientifique, Châtenay-Malabry, France), an instrument coupling time-resolved synchrotron X-ray diffraction as a function of temperature (XRDT) at both small and wide angles and high-sensitivity differential scanning calorimetry (DSC) at an intermediate $\left(1{ }^{\circ} \mathrm{C} \cdot \mathrm{min}^{-1}\right)$ and at a fast $\left(5^{\circ} \mathrm{C} \cdot \mathrm{min}^{-1}\right)$ cooling rate from 60 to $-20^{\circ} \mathrm{C}$, together with their subsequent melting at $1{ }^{\circ} \mathrm{C} \cdot \mathrm{min}^{-1}$. Upon cooling at $1{ }^{\circ} \mathrm{C} \cdot \mathrm{min}^{-1}$, the crystallization of ADMF started at about $24{ }^{\circ} \mathrm{C}$ with the formation of a lamellar structure with a $46.9 \AA$ period corresponding to a double-chain length molecular stacking and hexagonal chain packing $\left(2 \mathrm{~L}_{1} \alpha\right)$. From $20{ }^{\circ} \mathrm{C}$, a major crystalline species also with double-chain lengths of $42.5 \AA$ and orthorhombic chain packing $\left(2 \mathrm{~L}_{2} \beta^{\prime}\right)$ was observed. The successive crystallizations of varieties $2 \mathrm{~L}_{1}$ and $2 \mathrm{~L}_{2}$ were correlated with the apparition of two large exothermal events recorded simultaneously by thermal analysis (DSC). However, comparison of XRDT and DSC recordings revealed the presence of a third exothermal peak probably related to a transition $\alpha \rightarrow \beta^{\prime}$. At fast cooling $\left(5^{\circ} \mathrm{C} \cdot \mathrm{min}^{-1}\right)$ of ADMF, three crystalline varieties were formed: the $2 \mathrm{~L}_{1} \alpha(47.6 \AA), 2 \mathrm{~L}_{2} \beta^{\prime}(42.15 \AA)$ and a new crystalline structure with 4 chain lengths: $4 \mathrm{~L} \beta$ ' of period $84.5 \AA$, while three endotherms were recorded by DSC. This last crystalline form which had never been characterized until now, likely corresponds to the accumulation of defects in the stable $2 \mathrm{~L} \beta$ ' form $(42.15 \AA)$ resulting from fast cooling and then to a local lack of symmetry in the $4 \mathrm{~L}$ cell along the $\mathrm{c}$ axis of the crystals. This lack of symmetry was released during a transition $4 \mathrm{~L} \rightarrow 2 \mathrm{~L}$ observed upon heating. A polymorphic transition $\alpha \rightarrow \beta$, was always observed upon ADMF heating following cooling at either 5 or $1^{\circ} \mathrm{C} \cdot \mathrm{min}^{-1}$. Compared with the slow cooling at $0.1^{\circ} \mathrm{C} \cdot \mathrm{min}^{-1}$ which was studied in the previous paper of this series, ADMF presented different structural and thermal properties. Indeed, the cooling at $1{ }^{\circ} \mathrm{C} \cdot \mathrm{min}^{-1}$ and $5{ }^{\circ} \mathrm{C} \cdot \mathrm{min}^{-1}$ generated an unstable crystalline form $(\alpha)$ that was not found at slow cooling at $0.1^{\circ} \mathrm{C} \cdot \mathrm{min}^{-1}$. However, the major stable form $2 \mathrm{~L} \beta$ ' was always observed in the three types of cooling.
\end{abstract}

polymorphism / X-ray diffraction / differential scanning calorimetry / camel's milk

\footnotetext{
* Corresponding author ( 通讯作者): michel.ollivon@cep.u-psud.fr
} 
摘要 - 骆驼乳脂肪: 热和结构特性。2: 冷却速率的影响。本实验使用 Microcalix 测定骆驼 乳脂肪 (ADMF) 的结蕌性质, Microcalix 是时间分辨同步加速器 X 射线衍射仪 (XRDT) 和 高灵敏度的差示扫描量热计 (DSC) 联合使用的仪器, 以在小角和广角下记录的 X 射线衍射 数据作为温度的函数, 在 $60-20^{\circ} \mathrm{C}$ 的范围内以 $1^{\circ} \mathrm{C} \cdot \mathrm{min}^{-1}$ 和 $5{ }^{\circ} \mathrm{C} \cdot \mathrm{min}^{-1}$ 的冷却速率测定 $\mathrm{ADMF}$ 的结晶特性, 然后以 $1^{\circ} \mathrm{C} \cdot \mathrm{min}^{-1}$ 的速率加热样品, 测定样品的熔化特性。在以 $1{ }^{\circ} \mathrm{C} \cdot \mathrm{min}^{-1}$ 的速率冷却时, $\mathrm{ADMF}$ 的结晶点在 $24^{\circ} \mathrm{C}$, 相对应的衍射线是 $46.9 \AA$, 此时的晶体 为层状结构, 形成的长间隔结构是由双链长决定, 进一步确认为六方形堆积 $\left(2 \mathrm{~L}_{1} \alpha\right)$ 晶型 结构。在 $20^{\circ} \mathrm{C}$ 时, 主要晶型变型的衍射线是 $42.5 \AA$, 对应的也是双链长的分子堆积和正交 堆积 $(2 \mathrm{~L}, \beta)$ 。热分析 (DSC) 结果表明共有 3 个放热峰, 2 个晶型变型 $2 \mathrm{~L}_{1}$ 和 $2 \mathrm{~L}_{2}$ 对应着 2 个大的放热峰。根据对 XRDT 和 DSC 测定结果的比较分析认为第 3 个放热峰可能与 $\alpha \rightarrow \beta^{\prime}$ 转变有关。在以 $5^{\circ} \mathrm{C} \cdot \mathrm{min}^{-1}$ 的速率快速冷却 $\mathrm{ADMF}$ 时, 形成三种同质多晶: $2 \mathrm{~L}_{1} \alpha(47.6 \AA)$ 、 $\mathrm{L}_{2} \beta^{\prime}(42.15 \AA)$ 和 4 链长的 $4 \mathrm{~L} \beta^{\prime}(84.5 \AA)$ 晶型结构, 同样经 DSC 分析出现了 3 个放热峰。到目 前为止, 在其它乳脂肪中尚未发现 $4 \mathrm{~L} \beta^{\prime}(84.5 \AA)$ 晶型结构, 可能是由于快速冷却导致稳定 的 $2 \mathrm{~L} \beta$ ' (42.15 $\AA$ ) 晶型缺陷的积累, 使得 $4 \mathrm{~L}$ 晶胞中沿着晶体的 $\mathrm{c}$ 轴缺少对称性。在加热过 程中可以观察到在 $4 \mathrm{~L} \rightarrow 2 \mathrm{~L}$ 转变过程中这种不对称的现象得到了改善。对 $\mathrm{ADMF}$ 加热然后 以 5 或 $1{ }^{\circ} \mathrm{C} \cdot \mathrm{min}^{-1}$ 速率冷却时, 都能观察到 $\alpha \rightarrow \beta^{\prime}$ 这种多相态的转变。与慢速 $\left(0.1^{\circ} \mathrm{C} \cdot \mathrm{min}^{-1}\right)$ 冷却相比 (在另一篇文章中已经发表)，ADMF 表现出不同的结构和热特性。实际上在以 $1^{\circ} \mathrm{C} \cdot \mathrm{min}^{-1}$ 和 $5^{\circ} \mathrm{C} \cdot \mathrm{min}^{-1}$ 速率冷却时均产生了不稳定的 $\alpha$ 晶型, 而在慢速冷却 $\left(0.1^{\circ} \mathrm{C} \cdot \mathrm{min}^{-1}\right)$ 过程 中并没有发现 $\alpha$ 晶型。然而这 3 种冷却类型种都出现了稳定的 $2 \mathrm{~L} \beta$ ' 晶型。

\section{多晶型 / $\mathbf{X}$ 射线衍射 / 差示扫描量热计 / 骆驼奶}

Résumé - La matière grasse de lait de dromadaire : propriétés thermiques et structurales. 2. Influence de la vitesse de refroidissement. Dans cet article, qui est le deuxième d'une série, les propriétés structurales de la matière grasse anhydre extraite du lait de dromadaire (ADMF) ont été étudiées au cours de refroidissements à vitesse intermédiaire $\left(1^{\circ} \mathrm{C} \cdot \mathrm{min}^{-1}\right)$ et rapide $\left(5^{\circ} \mathrm{C} \cdot \mathrm{min}^{-1}\right)$ de $60^{\circ} \mathrm{C}$ à $-20^{\circ} \mathrm{C}$ suivis de chauffages à $1^{\circ} \mathrm{C} \cdot \mathrm{min}^{-1}$ grâce à Microcalix (Centre National de la Recherche Scientifique, Châtenay-Malabry, France), un appareil couplant la diffraction des rayons X en fonction de la température (DRXT) et la microcalorimétrie différentielle à balayage (DSC). A $1^{\circ} \mathrm{C} \cdot \mathrm{min}^{-1}$, la cristallisation des triglycérides de l'ADMF commence à environ $24^{\circ} \mathrm{C}$ avec la formation d'une structure lamellaire à 2 longueurs de chaînes de $46,9 \AA$ A et de sous-cellule hexagonale $\left(2 \mathrm{~L}_{1} \alpha\right)$. Pour $\mathrm{T} \leq 20^{\circ} \mathrm{C}$, une structure cristalline majoritaire également à 2 longueurs de chaînes de $42,5 \AA$ et de sous-cellule orthorhombique $\left(2 \mathrm{~L}_{2} \beta^{\prime}\right)$ se développe. Ces cristallisations successives sont corrélées avec l'apparition de deux pics exothermiques majeurs enregistrés simultanément par DSC. La comparaison des évolutions thermiques et structurales a révélé aussi la présence d'un troisième pic exothermique rattaché à une transition de phase $\alpha \rightarrow \beta$ '. Au cours du refroidissement rapide $\left(5{ }^{\circ} \mathrm{C} \cdot \mathrm{min}^{-1}\right)$ de $\mathrm{l}^{\prime} \mathrm{ADMF}$, la formation d'une nouvelle variété cristalline à 4 longueurs de chaînes de période $84,5 \AA$ A , notée $4 \mathrm{~L} \beta$ ', s'ajoute aux précédentes. La formation de cette dernière, qui n'avait jamais été caractérisée jusqu'à présent, a été attribuée à une accumulation de défauts dans la maille $4 \mathrm{~L}$ dans la direction $\mathrm{c}$ et à la perte de la symétrie qui la transformait en $2 \mathrm{~L} \beta$ '. Cette absence de symétrie est relaxée lors d'une transition $4 \mathrm{~L} \rightarrow 2 \mathrm{~L}$ observée au chauffage. Une transition polymorphique $\alpha \rightarrow \beta$ ' est toujours observée lors du chauffage de l'ADMF suite à son refroidissement rapide à $5 \mathrm{ou} 1 \cdot \mathrm{min}^{-1}$. Comparé au refroidissement lent à $0,1^{\circ} \mathrm{C} \cdot \mathrm{min}^{-1}$ (étudié dans l'article précédent de cette série), l'ADMF présente des propriétés structurales et thermiques différentes. En effet, les refroidissements à $1^{\circ} \mathrm{C} \cdot \mathrm{min}^{-1}$ et à $5^{\circ} \mathrm{C} \cdot \mathrm{min}^{-1}$ génèrent une forme instable $\alpha$ qui n'a pas été trouvée lors du refroidissements lent à $0,1^{\circ} \mathrm{C} \cdot \mathrm{min}^{-1}$. Cependant, la forme stable majoritaire $2 \mathrm{~L}$ $\beta$ ' est toujours conservée aux trois vitesses de refroidissement.

polymorphisme / diffraction des rayons $\mathrm{X}$ / microcalorimétrie différentielle à balayage / lait de dromadaire

\section{INTRODUCTION}

Camels (Camelus dromedarius) are important dairy animals in certain regions of the world. Although data on the general composition of camel's milk is reported by several sources $[3,11,12,26]$, data on the chemical and physical properties of anhydrous 
dromedary milk fat (ADMF), which is the fat isolated from butter, are still scarce. ADMF is an essential nutriment in desert areas with a complex fatty acid composition $[2,5,8]$, which has already been discussed in the first article of this series [9]. As observed for other fats and in the previous study [9], the coupling of X-ray diffraction (XRD) as a function of temperature (XRDT) and differential scanning calorimetry (DSC) is the best technique to characterize the structural and thermal behavior of ADMF $[14-21,25]$. XRD permits the study of the various lamellar structures formed by triacylglycerols (TG). The longitudinal stacking of the TG molecules and the lateral packing of their acylglycerol chains are recorded at small and wide angles, respectively, as detailed in [14]. DSC permits characterization of the thermal properties of complex fat which depend on the thermal treatments applied to fat $[6,27,28]$.

Surprisingly, in spite of the broad diversity of TG present in ADMF, a single crystalline form, characterized by a single sharp and narrow line by XRD at small angles, was found in the previous study [9]. This specific behavior which was hypothetically related to the fluctuations of day to night and camel body temperatures, again raises the question of the molecular TG packing in such complex fats.

In this paper, we examined the crystalline structures formed by TG during cooling of ADMF at intermediate $\left(1^{\circ} \mathrm{C} \cdot \mathrm{min}^{-1}\right)$ and fast $\left(5^{\circ} \mathrm{C} \cdot \mathrm{min}^{-1}\right)$ cooling rates. The evolution as a function of temperature of the crystalline structures formed during cooling at $0.1{ }^{\circ} \mathrm{C} \cdot \mathrm{min}^{-1}$ followed by heating at $1{ }^{\circ} \mathrm{C} \cdot \mathrm{min}^{-1}$ in the preceding paper of the series was also considered to make a synthesis on the influence of the cooling rate on the thermal and structural behavior of ADMF.

\section{MATERIALS AND METHODS}

\subsection{Samples}

Dromedary milk (Camelus dromedarius) was supplied by the Institute of Arid Regions' herd (IRA, Medenine, Tunisia).
Cream was obtained from the camel's milk after centrifugation three times at $25^{\circ} \mathrm{C}$ and $3000 \mathrm{~g}$ for $20 \mathrm{~min}$ on a Jouan GR20-22 centrifuge (Jouan, Saint-Herblain, France). Anhydrous dromedary milk fat (ADMF) was extracted from the cream as previously described in [9].

\subsection{Combined XRDT and DSC measurements}

Experiments were conducted using Microcalix (Centre National de la Recherche Scientifique, Châtenay-Malabry, France), an apparatus allowing simultaneous timeresolved synchrotron X-ray diffraction as a function of temperature (XRDT) and high sensitivity differential scanning calorimetry (DSC) to be carried out on the same sample, as reported previously [4, 9, 15, 19, 23]. The recording of XRDT patterns and the calibration of the detectors and the calorimeter were conducted as previously reported $[4,9,10,19,23]$. The analysis of the XRDT patterns was performed as previously described $[9,14]$.

The crystallization behavior of ADMF samples was conducted upon cooling at $1^{\circ} \mathrm{C} \cdot \mathrm{min}^{-1}$ and $5^{\circ} \mathrm{C} \cdot \mathrm{min}^{-1}$ from 60 to $-20^{\circ} \mathrm{C}$. The melting behavior was monitored just after cooling (about $10 \mathrm{~s}$, the time needed to program the heat treatment) by heating of the ADMF sample at $1^{\circ} \mathrm{C} \cdot \mathrm{min}^{-1}$ from $-20^{\circ} \mathrm{C}$ to $60^{\circ} \mathrm{C}$. All recordings were obtained from the same sample of $26.83 \mathrm{mg}$.

\section{RESULTS AND DISCUSSION}

\subsection{Crystallization behavior of ADMF at an intermediate cooling rate $\left(1^{\circ} \mathrm{C} \cdot \mathrm{min}^{-1}\right)$ and subsequent heating at $1^{\circ} \mathrm{C} \cdot \mathrm{min}^{-1}$}

\subsubsection{Crystalline structures formed upon cooling at $1^{\circ} \mathrm{C} \cdot \mathrm{min}^{-1}$}

XRD patterns recorded simultaneously at small and wide angles as a function of temperature during cooling of ADMF are presented in Figure 1, as three-dimensional plots. The small-angle XRDT patterns 
A

$2 \mathrm{~L}_{2}$

42.15A

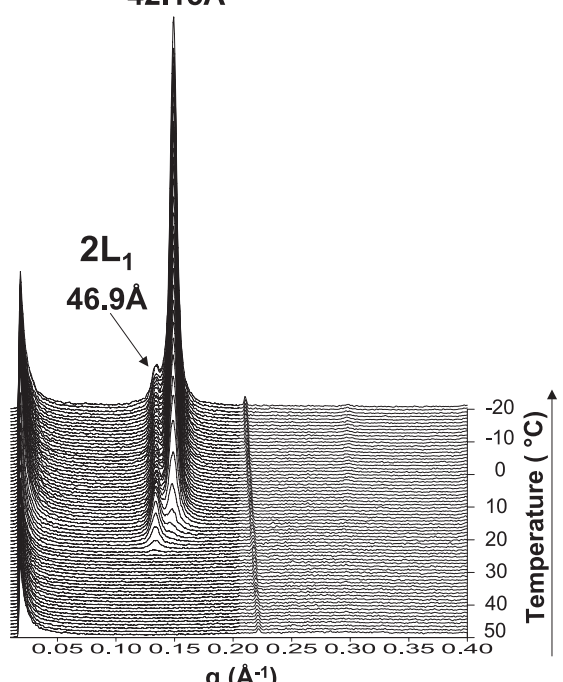

B

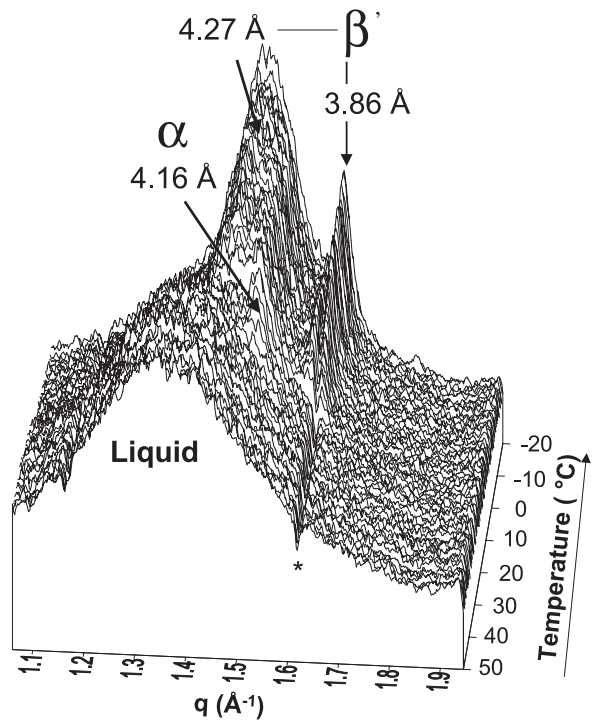

Figure 1. Three-dimensional plots of small- (A) and wide- $(\mathbf{B})$ angle X-ray diffraction patterns recorded as a function of time during cooling of anhydrous dromedary milk fat at $1{ }^{\circ} \mathrm{C} \cdot \mathrm{min}^{-1}$ using coupled XRDT-DSC (* asterisk symbol corresponds to negative peak due to the wide-angle detector defects). The crystalline structures identified are noted in the figure.

(Fig. 1A) show the progressive development of two diffraction lines corresponding to crystallization of TG in dromedary milk fat, as a function of temperature. Crystallization of dromedary milk fat TG starts by the appearance, at about $24^{\circ} \mathrm{C}$, of a diffraction line at $\mathrm{q}=0.13 \AA^{-1}(46.9 \AA)$. This first crystalline form corresponds to a lamellar structure with a longitudinal organization of molecules in a double-chain length stacking (2L). Next to this weak XRD peak, a major diffraction line, at about $20{ }^{\circ} \mathrm{C}$, which increases in intensity upon cooling is also recorded at $q=0.15 \AA^{-1}(42.15 \AA)$ with a weak second order at $q=0.30 \AA^{-1}$ (about $21 \AA$ ). This same crystalline structure has been previously observed at small angles for the slow cooling of the ADMF at $0.1{ }^{\circ} \mathrm{C} \cdot \mathrm{min}^{-1}$ as a single line [9]. The small peak recorded at about $\mathrm{q}=0.2-0.225 \AA^{-1}$ from the beginning of the experiment at $\mathrm{T}=50^{\circ} \mathrm{C}$ is attributed hypothetically to the presence of waxy lipids in the extracted fat since more polar lipids would be expected to form a bilayer of much larger period, as discussed in [9].

The wide-angle XRD patterns simultaneously recorded as a function of temperature (Fig. 1B) can be divided into three $\mathrm{T}$ ranges. A single $\mathrm{X}$-ray scattering bump centered at $\mathrm{q}=1.38 \AA^{-1}(4.55 \AA)$ is recorded from $50{ }^{\circ} \mathrm{C}$ to about $\mathrm{T}=20^{\circ} \mathrm{C}$, meaning that all the $\mathrm{TG}$ are in a liquid state according to [13]. This bump decreases in intensity at lower temperatures as crystallization develops. From about $\mathrm{T}=24-25^{\circ} \mathrm{C}$, a diffraction line centered at $\mathrm{q}=1.51 \AA^{-1}(4.16 \AA)$ corresponds to a first organization of the lateral packing of the alkyl chain of TG in milk fat. This line corresponds to the formation of a hexagonal packing of the chains, also called the $\alpha$ form, which is the least stable of the possible crystalline arrangements of the TG chains. At about $20^{\circ} \mathrm{C}$, the occurrence of two diffraction lines centered at $\mathrm{q}=1.63 \AA^{-1}$ $(3.86 \AA)$ and $q=1.47 \AA^{-1}(4.27 \AA)$ indicates the formation of a new crystalline arrangement of TG in ADMF, corresponding to an 


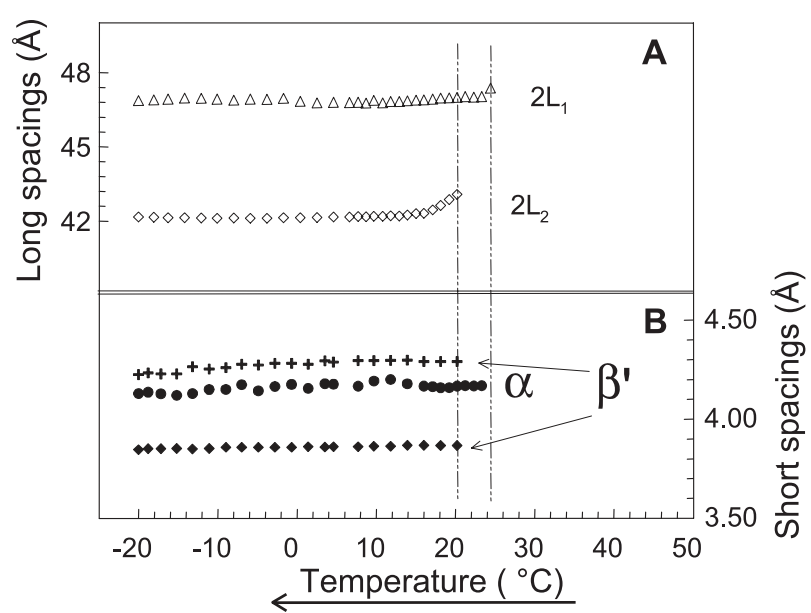

Figure 2. Evolution of the (A) long and (B) short spacings of anhydrous dromedary milk fat crystals shown in Figure 1 during cooling at $1{ }^{\circ} \mathrm{C} \cdot \mathrm{min}^{-1}$.

orthorhombic packing of the chains also called the $\beta$ ' form.

\subsubsection{Structural analysis: spacing evolution}

The evolution versus $\mathrm{T}$ of the long and short spacings determined from the diffraction peaks recorded at small and wide angles, respectively (Figs. 1A, 1B), are shown in Figures $2 \mathrm{~A}$ and $2 \mathrm{~B}$.

The two diffraction lines recorded at small angles correspond to bilayered structures with thicknesses of $46.9 \AA\left(2 \mathrm{~L}_{1}\right)$ and $42.15 \AA\left(2 \mathrm{~L}_{2}\right)$ in their order of formation during cooling of ADMF. No significant evolution in the long spacing for the line $2 \mathrm{~L}_{1}(46.9 \AA)$ is observed. On the other hand, for the line $2 \mathrm{~L}_{2}$, between about $20^{\circ} \mathrm{C}$ and $16^{\circ} \mathrm{C}$, the mean thickness of this lamellar structure decreases from $43.2 \AA$ to $42.15 \AA$ during cooling of ADMF (Fig. 2A). This structure stabilizes between 16 and $-20^{\circ} \mathrm{C}$. This decrease in the thickness is attributed to the progressive incorporation of TG with shorter FA chains and/or with a monounsaturated FA to the crystals of those with long-chain saturated FA that crystallized first.
The short spacing does not show a significant evolution during cooling (Fig. 2B). This means that no change occurs in the lateral packing of FA chains as a function of temperature.

\subsubsection{Structural analysis: intensity evolution}

The evolution of maximum intensity of the XRD peaks recorded during cooling of $\mathrm{ADMF}$ is presented in Figures $3 \mathrm{~A}$ and $3 \mathrm{~B}$ as a function of temperature. Three T ranges were observed both at small and wide angles.

At small angles (Fig. 3A), the intensity of the $2 \mathrm{~L}_{1}$ line ( $46.9 \AA$ ) strongly and quickly increased from its formation at about $24^{\circ} \mathrm{C}$ to $18^{\circ} \mathrm{C}$ (first $\mathrm{T}$ range). Between $18^{\circ} \mathrm{C}$ and $4{ }^{\circ} \mathrm{C}$ (second $\mathrm{T}$ range), the intensity of the $2 \mathrm{~L}_{2}$ line increased partially at the expense of the $2 \mathrm{~L}_{1}$ line, the intensity of which decreases by about $40 \%$, meaning that a certain amount of TG molecules transforms from $2 \mathrm{~L}_{1}$ into $2 \mathrm{~L}_{2}$. Finally, from $4{ }^{\circ} \mathrm{C}$ until the end of the cooling process at $-20{ }^{\circ} \mathrm{C}$ (third $\mathrm{T}$ range), the $2 \mathrm{~L}_{1}$ line stabilizes in intensity whereas the $2 \mathrm{~L}_{2}$ line is still continuously increasing, meaning that the 


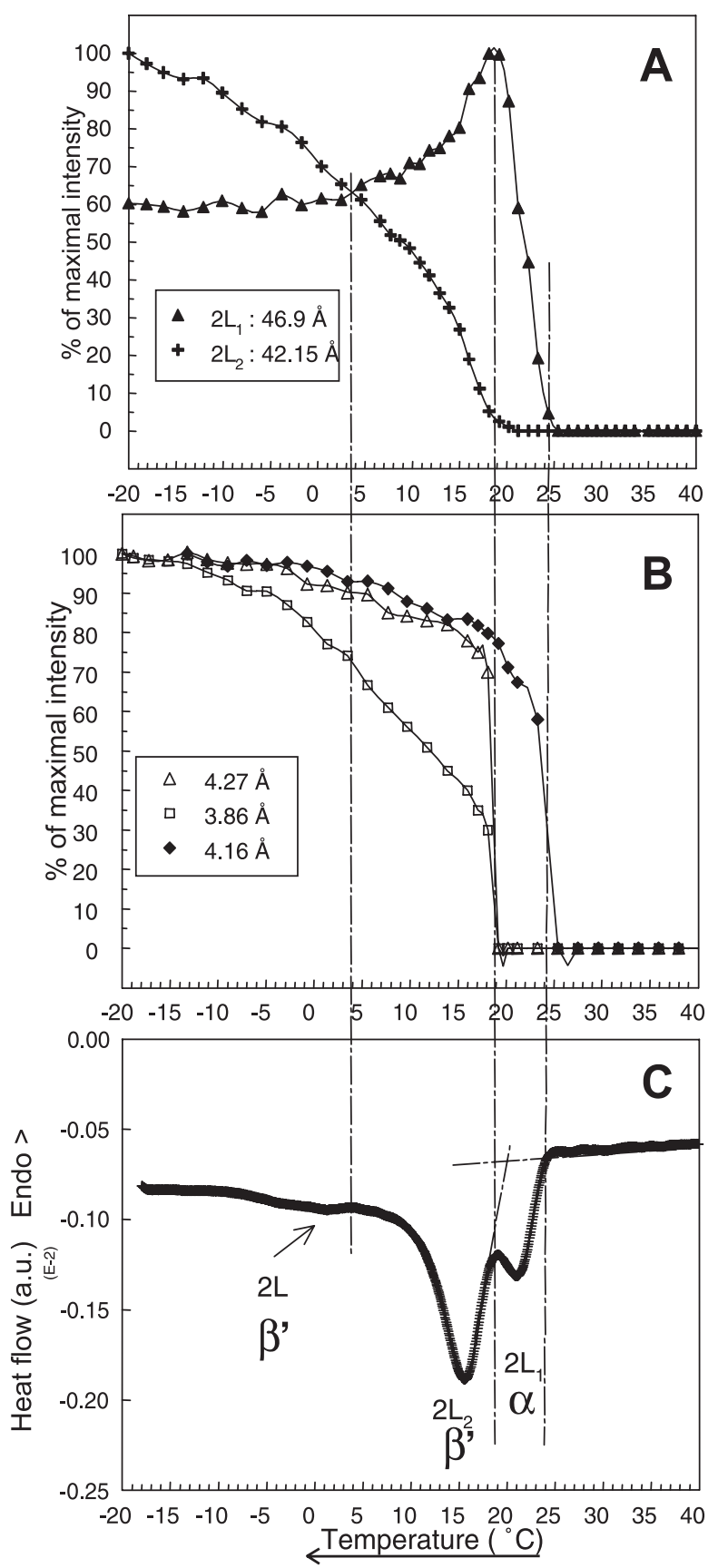

Figure 3. Evolution of the maximal intensities of the diffraction peaks recorded in Figure $1(100 \%$ corresponds to the strongest peak). (A) Evolution of the long spacings. (B) Evolution of the short spacings. (C) DSC crystallization curve recorded simultaneously during cooling of anhydrous dromedary milk fat at $1^{\circ} \mathrm{C} \cdot \mathrm{min}^{-1}$. 
crystallization process is not yet finished at this temperature.

At wide angles (Fig. 3B), in the first $\mathrm{T}$ range, the $\alpha$ form strongly increases in intensity. This increase is parallel to that of the $2 \mathrm{~L}_{1}$ line (Fig. 3A). It permits us to assign this $2 L_{1}$ organization to an $\alpha$ form $\left(2 L_{1} \alpha\right)$. In the second $T$ range, the $\beta$ ' form increases considerably in intensity. This increase is parallel to that of the $2 \mathrm{~L}_{2}$ line (Fig. 3A). Therefore, the second crystal type formed during the cooling of ADMF at $1{ }^{\circ} \mathrm{C} \cdot \mathrm{min}^{-1}$ is $2 \mathrm{~L}_{2} \beta$ '. In the third T range, the intensity of the $\alpha$ form stabilizes, whereas the $\beta$ ' one keeps on increasing. It is not at all surprising to evidence this unstable $\alpha$ form that has not been observed upon cooling of the ADMF at $0.1{ }^{\circ} \mathrm{C} \cdot \mathrm{min}^{-1}$ since $1{ }^{\circ} \mathrm{C} \cdot \mathrm{min}^{-1}$ is a fast cooling compared with $0.1^{\circ} \mathrm{C} \cdot \mathrm{min}^{-1}$.

\subsubsection{Thermal properties upon cooling at $1^{\circ} \mathrm{C} \cdot \mathrm{min}^{-1}$}

The DSC crystallization curve was recorded simultaneously with XRD from the same sample of ADMF during its cooling at $1{ }^{\circ} \mathrm{C} \cdot \mathrm{min}^{-1}$, thanks to XRDT/DSC coupling (Fig. 3C). The DSC recording shows three exothermic peaks which can be related to the formation of the lamellar structures analyzed above (Figs. 2A, 2B). The crystal types are noted in Figure 3C below the exothermic peaks to which they are attributed. The initial crystallization temperature is $24^{\circ} \mathrm{C}$. The first exothermal event recorded upon cooling from $24{ }^{\circ} \mathrm{C}$ corresponds to the formation of the crystalline structure $2 \mathrm{~L}_{1} \alpha$ characterized by XRD from the same temperature.

The second exothermal event recorded from about $19^{\circ} \mathrm{C}$ to $6^{\circ} \mathrm{C}$ during cooling of ADMF corresponds to crystallization of TG incorporated in the bilayered structure $2 \mathrm{~L}_{2} \beta$ '. The third weak exotherm observed between $4^{\circ} \mathrm{C}$ and $-10^{\circ} \mathrm{C}$ was interpreted as the formation of the $\beta$ ' form because this crystalline variety forms between $4{ }^{\circ} \mathrm{C}$ and $-20{ }^{\circ} \mathrm{C}$, in the same interval of temperatures, while the $\alpha$ form intensity is stable. This first analysis is not complete since the exotherm necessarily associated with the transition $\alpha \rightarrow \beta$ ' has not been taken into account. This exotherm necessarily super- imposes on the three exotherms discussed above. Its amplitude should not be neglected, taking into account that it concerns about $40 \%$ of the TG crystallized in the $\alpha$ form. Thus, part of the amplitude of the second exotherm is due to the exothermic character of this transition. The double jump observed in the increase in the intensity of the smallangle XRD line at $42.15 \AA$ (Fig. 3A) should be related to this event as well as to the formation of a second variety.

\subsubsection{Heating of ADMF at $1^{\circ} \mathrm{C} \cdot \mathrm{min}^{-1}$ subsequent to cooling at $1{ }^{\circ} \mathrm{C} \cdot \mathrm{min}^{-1}$}

Following crystallization upon cooling at $1{ }^{\circ} \mathrm{C} \cdot \mathrm{min}^{-1}$, the $\mathrm{ADMF}$ sample was heated at $1{ }^{\circ} \mathrm{C} \cdot \mathrm{min}^{-1}$ from $-20^{\circ} \mathrm{C}$ to $60^{\circ} \mathrm{C}$ in order to follow the evolution of the crystalline species formed during cooling.

\subsubsection{Structural analysis}

The plot of the XRD patterns recorded as a function of time versus temperature as a $3 \mathrm{D}$ viewing, at small and wide angles, are presented in Figures $4 \mathrm{~A}$ and $4 \mathrm{~B}$, respectively.

The small-angle plot (Fig. 4A) shows successively, as a function of temperature, the decrease in intensity of the diffraction lines characteristic of the $2 \mathrm{~L}_{1}$ and $2 \mathrm{~L}_{2}$ species until their final melting. Indeed, in the interval of temperature $-20^{\circ} \mathrm{C}<\mathrm{T}<22.5^{\circ} \mathrm{C}$, the $2 \mathrm{~L}_{1}$ line disappears while the $2 \mathrm{~L}_{2}$ line continuously vanishes in the range $-5{ }^{\circ} \mathrm{C}<\mathrm{T}<42.5^{\circ} \mathrm{C}$. It is interesting to note that the decrease in the intensity of the $2 \mathrm{~L}_{2}$ line is apparently quite linear over this range of temperature. However, it shows a small inflexion of the curve just as the $2 \mathrm{~L}_{1}$ line melts.

XRDT data recorded at wide angles (Fig. 4B) show the coexistence of the $\alpha+$ $\beta$ ' forms from $-20^{\circ} \mathrm{C}$ to the melting of the unstable $\alpha$ form at $\mathrm{T}=21{ }^{\circ} \mathrm{C}$. Above this temperature the orthorhombic packing of the alkyl chains ( $\beta$ ' form) is only seen until the final melting point of ADMF toward $42{ }^{\circ} \mathrm{C}$. For $\mathrm{T}>42{ }^{\circ} \mathrm{C}$, the absence of diffraction peaks at small angles and the recording of the broad peak of scattering 
A $2 \mathrm{~L}_{2}$

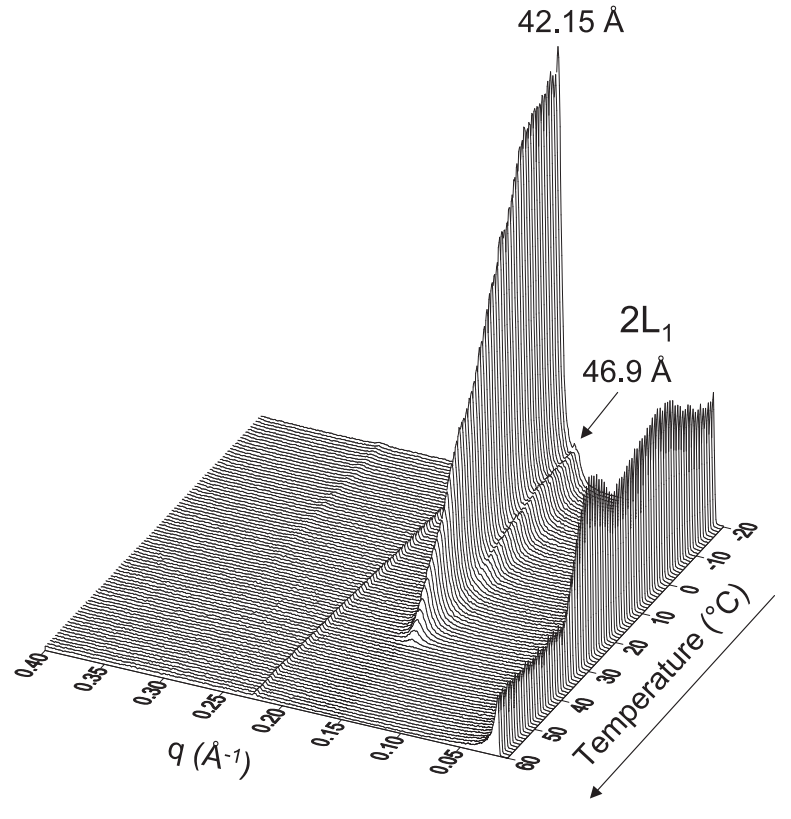

B

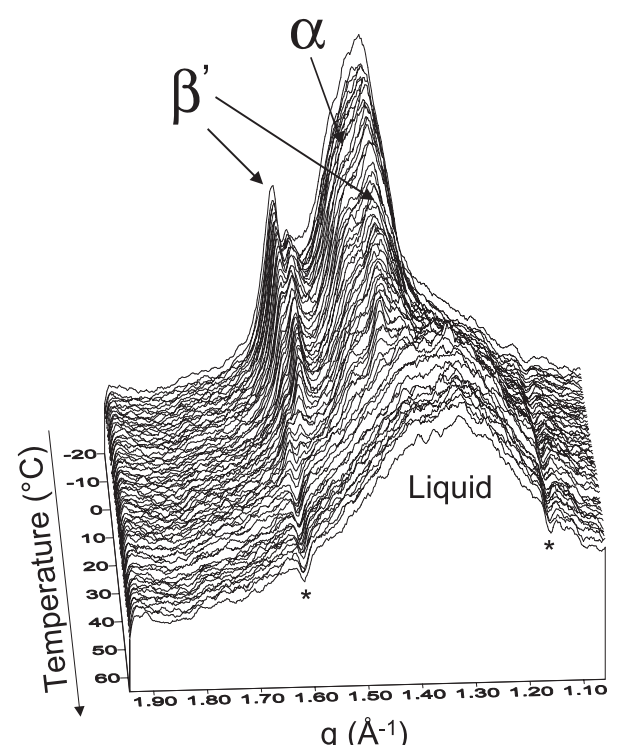

$q\left(\AA^{-1}\right)$

Figure 4. Three-dimensional plots of small- (A) and wide- (B) angle X-ray diffraction patterns recorded as a function of time during heating of anhydrous dromedary milk fat at $1{ }^{\circ} \mathrm{C} \cdot \mathrm{min}^{-1}$ after cooling at $1^{\circ} \mathrm{C} \cdot \mathrm{min}^{-1}(*$ asterisk symbol corresponds to negative peak due to the wide-angle detector defects). The crystalline structures identified are noted in the figure. 


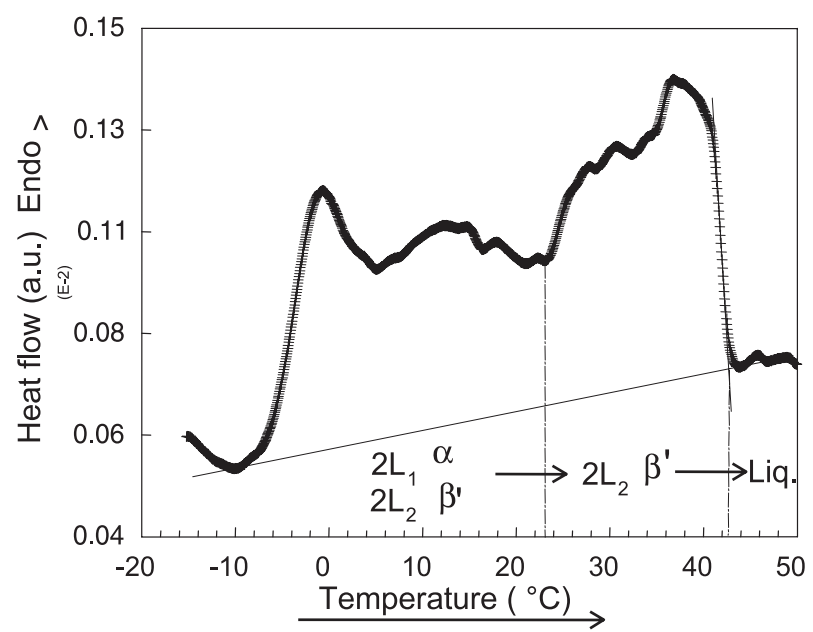

Figure 5. DSC melting curve recorded simultaneously during heating of anhydrous dromedary milk fat at $1{ }^{\circ} \mathrm{C} \cdot \mathrm{min}^{-1}$ after cooling at $1{ }^{\circ} \mathrm{C} \cdot \mathrm{min}^{-1}$. Melting ranges of the different species are indicated at the bottom.

observed at wide angles means that all TG of ADMF are in their liquid state. The fact that $2 \mathrm{~L}_{1}$ (unstable form) melts before $2 \mathrm{~L}_{2}$ (Fig. 4A) is not surprising. The facts that (i) the decrease in the $2 \mathrm{~L}_{1}$ line coincides with that of the $\alpha$ form, and (ii) the melting of the $2 \mathrm{~L}_{2}$ line follows that of the $\beta^{\prime}$ form (Fig. 4B), confirm the association of structures $2 \mathrm{~L}_{1} \alpha$ and $2 \mathrm{~L}_{2} \beta$ ' as explained above and below.

\subsubsection{Thermal analysis}

The DSC curve recorded simultaneously with the small- and wide-angle XRD during heating at $1{ }^{\circ} \mathrm{C} \cdot \mathrm{min}^{-1}$ of the ADMF sample is presented in Figure 5.

First of all, the signal recorded by the DSC between $-20^{\circ} \mathrm{C}$ and $-10^{\circ} \mathrm{C}$ should not be taken into consideration since it corresponds to equilibration of the calorimeter. Figure 5 shows the overlapping of several endotherms until the final melting temperature at about $42^{\circ} \mathrm{C}$. They appear as a modulation of a trapezoidal shaped peak. A constant signal would be indicative of a continuous melting. These endotherms can be divided into three $\mathrm{T}$ ranges thanks to XRDT recordings. The first melting $\mathrm{T}$ range is located in the range $-5<\mathrm{T}<5^{\circ} \mathrm{C}$.
It can be assigned to the melting of the crystalline $2 \mathrm{~L}_{2} \beta^{\prime}$ form. The second, which is observed in the range $5<\mathrm{T}<25{ }^{\circ} \mathrm{C}$, coincides with the melting of $2 \mathrm{~L}_{1} \alpha$ superimposed onto some melting of $2 \mathrm{~L}_{2} \beta$ '. The last endotherm corresponds to that of $2 \mathrm{~L}_{2} \beta^{\prime}$. At $\mathrm{T} \geq 42{ }^{\circ} \mathrm{C}$, ADMF is fully melted in agreement with XRDT data showing that all TG are liquid.

\subsection{Crystallization behavior of ADMF at a fast cooling rate $\left(5^{\circ} \mathrm{C} \cdot \mathrm{min}^{-1}\right)$ and subsequent heating at $1^{\circ} \mathrm{C} \cdot \mathrm{min}^{-1}$}

\subsubsection{Crystalline structures formed upon cooling at $5^{\circ} \mathrm{C} \cdot \mathrm{min}^{-1}$}

ADMF was cooled in the glass capillaries of the coupled XRDT/DSC apparatus from $60{ }^{\circ} \mathrm{C}$ to $-20{ }^{\circ} \mathrm{C}$ with a cooling rate of $5^{\circ} \mathrm{C} \cdot \mathrm{min}^{-1}$ in order to study the formation of unstable crystalline forms of TG. The plot of the XRD patterns recorded as a function of temperature versus temperature as a $3 \mathrm{D}$ viewing, at both small and wide angles during cooling of ADMF at $5^{\circ} \mathrm{C} \cdot \mathrm{min}^{-1}$ are presented in Figure 6. In the $60>\mathrm{T}>20{ }^{\circ} \mathrm{C}$ $\mathrm{T}$ range, XRD patterns recorded at both 
A

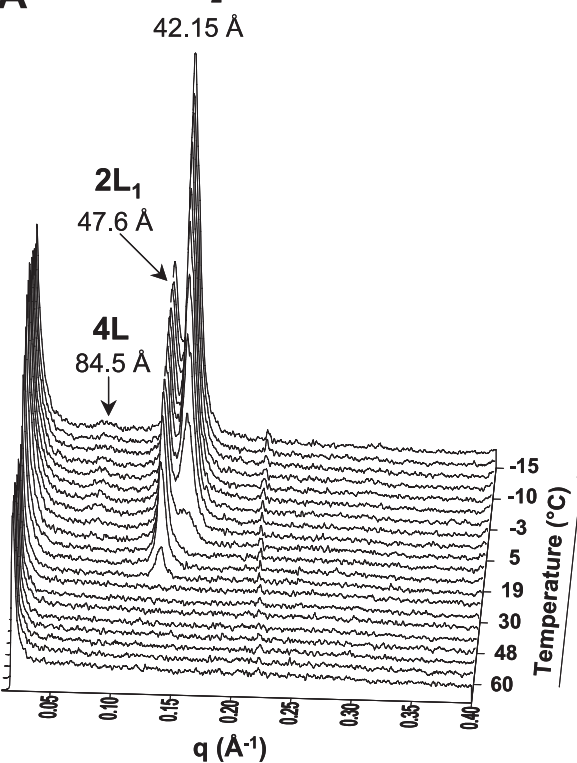

B

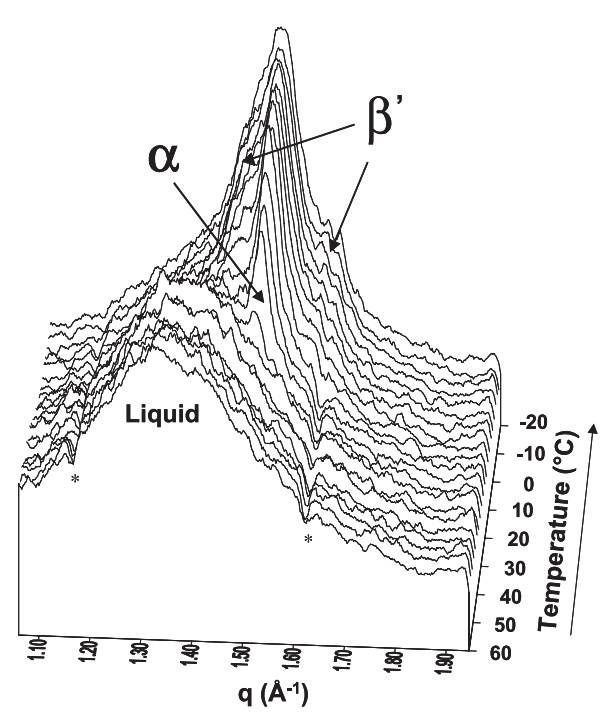

Figure 6. Three-dimensional plots of small- (A) and wide- (B) angle X-ray diffraction patterns recorded as a function of time during cooling of anhydrous dromedary milk fat at $5{ }^{\circ} \mathrm{C} \cdot \mathrm{min}^{-1}$ using coupled XRDT-DSC (* asterisk symbol corresponds to negative peak due to the wide-angle detector defects). The crystalline structures identified are noted in the figure.

small (Fig. 6A) and wide (Fig. 6B) angles show that milk fat $\mathrm{TG}$ are in their liquid state while for $\mathrm{T}<20^{\circ} \mathrm{C}$, the recording of diffraction lines at both small and wide angles corresponds to TG crystallization.

At small angles (Fig. 6A), TG crystallization is related to the recording of three XRD peaks at about $q=0.16 \AA^{-1}(42.15 \AA)$, $\mathrm{q}=0.13 \AA^{-1}(47.6 \AA)$ and about $q=0.075 \AA^{-1}(84.5 \AA)$. All the diffraction lines increase in intensity as a function of the decrease in temperature. The crystalline form with a period of $47.6 \AA$ corresponds to a lamellar structure with a double-chain length organization (2L) of the TG molecules, called $2 \mathrm{~L}_{1}$. Then, a major sharp diffraction line is recorded at $42.15 \AA$ and is attributed to the formation of a bilayered lamellar structure $\left(2 \mathrm{~L}_{2}\right)$. A weak XRD bump, corresponding to the formation of a new variety with a thickness of $84.5 \AA$, is recorded. This structure has not been observed upon cooling previously either at the slow cooling of $0.1^{\circ} \mathrm{C} \cdot \mathrm{min}^{-1}$ [9] or at that of $1{ }^{\circ} \mathrm{C} \cdot \mathrm{min}^{-1}$ (see above). A distance equal to $84.5 \AA$ should be attributed to crystalline forms with a four-chain length stacking (4L). Indeed, considering the fatty acid composition of the ADMF whose longest chain is C20:0 [1, 7, 8, 24, 26] and calculating the total chain length of a TG trisaturated in C20:0 in a 3L stacking, then one would have a value of about $76.2 \AA$. This value is by far lower than $84.5 \AA$, bringing us to conclude that the $84.5 \AA$ period corresponds to a $4 \mathrm{~L}$ variety and not $3 \mathrm{~L}$. It is of interest to note that such crystalline $4 \mathrm{~L}$ structures have never been identified in anhydrous bovine milk fat (ABMF) when it is cooled at different rates [21]. Taking into account the difference in composition in FA and necessarily in TG between the milks of these two species, this is not at all surprising [8]. Therefore, this should be considered as a characteristic of dromedary milk fat.

At wide angles (Fig. 6B), the diffraction line recorded at $4.15 \AA$, visible from about $\mathrm{T}=24^{\circ} \mathrm{C}$, is characteristic of TG crystallization 
with a hexagonal packing of the acylglycerol chain ( $\alpha$ form). From about $4{ }^{\circ} \mathrm{C}$, two diffraction lines recorded at $3.88 \AA$ and $4.27 \AA$ correspond to an organization of the lateral packing of the alkyl chains of TG in ADMF, corresponding to an orthorhombic packing of the chains ( $\beta$ ' form). All XRD patterns recorded at small angles during cooling of $\mathrm{ADMF}$ at $5{ }^{\circ} \mathrm{C} \cdot \mathrm{min}^{-1}$ were analyzed to determine the position and the maximal intensity of each diffraction peak as a function of temperature in order to delimit the $\mathrm{T}$ ranges of existence of the crystalline varieties.

The evolutions of the long spacing recorded at small angles during cooling of $\mathrm{ADMF}$ at $5{ }^{\circ} \mathrm{C} \cdot \mathrm{min}^{-1}$ are not presented since the long spacing of $4 \mathrm{~L}, 2 \mathrm{~L}_{1}$ and $2 \mathrm{~L}_{2}$ do not show any significant evolution as a function of temperature.

The evolutions as a function of temperature of maximal intensities of each diffraction peak recorded at small angles during cooling of ADMF are presented in Figure 7A. The weak intensity of peaks and noise at the position-sensitive detector prevented us from analyzing the wide-angle XRD data. The intensity of $\alpha$ and $2 \mathrm{~L}_{1}$ lines strongly increases from their formation at about $20{ }^{\circ} \mathrm{C}$ to $6{ }^{\circ} \mathrm{C}$. Then, from $6{ }^{\circ} \mathrm{C}$ until the end of the cooling process at $-20^{\circ} \mathrm{C}$, these lines do not show any evolution. As the evolution of the intensity of the $\alpha$ form follows precisely that of $2 \mathrm{~L}_{1}$, we deduced that they are related to the same structure, $2 \mathrm{~L}_{1} \alpha$. For the 4L line, Figure 7A shows a significant increase in intensity at $4{ }^{\circ} \mathrm{C}$ until $-10{ }^{\circ} \mathrm{C}$, which then tends to stabilize toward $-10^{\circ} \mathrm{C}$. In the same interval of temperature the $\alpha$ form does not show any evolution in intensity, meaning that the line $4 \mathrm{~L}$ cannot be related to the $\alpha$ form but rather to the $\beta$ ' form; $4 \mathrm{~L}$ $\beta$ '. The intensity of the $2 L_{2}$ line increases continuously and significantly from $6{ }^{\circ} \mathrm{C}$ to $-20^{\circ} \mathrm{C}$. This line is also associated with a $\beta$, form, called $2 \mathrm{~L}_{2} \beta$ '.

\subsubsection{Thermal properties upon cooling at $5^{\circ} \mathrm{C} \cdot \mathrm{min}^{-1}$}

The crystallization curve recorded by DSC simultaneously with XRDT experiments during the cooling of ADMF at $5^{\circ} \mathrm{C} \cdot \mathrm{min}^{-1}$ is presented in Figure $7 \mathrm{~B}$.

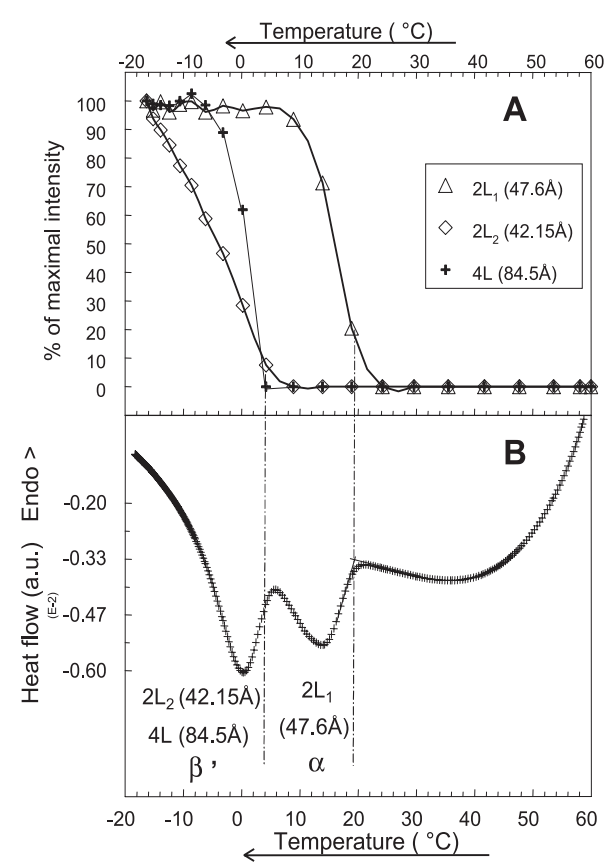

Figure 7. Evolution of the maximal intensities of the diffraction peaks recorded in Figure 6 ( $100 \%$ corresponds to the strongest peak). (A) Evolution of the long spacings, (B) DSC crystallization curve recorded simultaneously during cooling of anhydrous dromedary milk fat at $5^{\circ} \mathrm{C} \cdot \mathrm{min}^{-1}$.

Coupling of XRDT and DSC measurements on the sample of ADMF allows one to relate the structural and the thermal behavior of TG as a function of temperature and to identify the DSC peaks. The shape of the DSC curve, above $20^{\circ} \mathrm{C}$, corresponds to the equilibration of the calorimeter. From the initial temperature of crystallization measured at $20^{\circ} \mathrm{C}$, two exothermal events are recorded. The first exotherm is related to crystallization of the $2 \mathrm{~L}_{1} \alpha(47.6 \AA)$ variety. The second exotherm corresponds to crystallization of the $2 \mathrm{~L}_{2} \beta^{\prime}(42.15 \AA)$ and $4 \mathrm{~L} \beta$ ' $(84.5 \AA)$ varieties with an initial temperature of crystallization measured at $6^{\circ} \mathrm{C}$.

\subsubsection{Heating at $1^{\circ} \mathrm{C} \cdot \mathrm{min}^{-1}$ subsequent to cooling at $5^{\circ} \mathrm{C} \cdot \mathrm{min}^{-1}$}

After cooling at $5^{\circ} \mathrm{C} \cdot \mathrm{min}^{-1}$, the ADMF sample was heated from $-20^{\circ} \mathrm{C}$ to $60^{\circ} \mathrm{C}$ at 
$1{ }^{\circ} \mathrm{C} \cdot \mathrm{min}^{-1}$ in order to study the polymorphic evolution of the crystalline structures formed.

\subsubsection{Structural analysis}

XRDT patterns recorded simultaneously at small and wide angles during heating of ADMF are plotted as $3 \mathrm{D}$ views Figures $8 \mathrm{~A}$ and $8 \mathrm{~B}$, respectively.

The small-angle plot shows that the intensity of the peak corresponding to the $2 \mathrm{~L}_{2}$ structure starts to decrease, then it increases considerably before decreasing again for final melting. The line $2 \mathrm{~L}_{1}$, shows a constant intensity followed by a sharp decrease as previously. The decrease in the line of period $4 \mathrm{~L}$ is difficult to delimit precisely. The wide angles' thermal evolution shown in Figure $8 \mathrm{~B}$ enabled us to evidence coexistence of $\alpha+\beta$ ' forms at $-20^{\circ} \mathrm{C}$. Then, the $\alpha$ form melts first leaving the $\beta$ 'form, which in turn disappears over about $42.5^{\circ} \mathrm{C}$, leading to the broad peak centered at $\mathrm{q}=1.35 \AA^{-1}$ characteristic of the alkyl chain liquid state [13].

\subsubsection{Spacing evolution}

A significant decrease in the thickness of the $84.5 \AA$ structure is observed from -2 to $19{ }^{\circ} \mathrm{C}$ (Fig. 9A). On the other hand, from $10{ }^{\circ} \mathrm{C}$ to about $18^{\circ} \mathrm{C}$, the form $2 \mathrm{~L}_{1}(47.6 \AA)$ (Fig. 9B) sharply decreases from $47.03 \AA$ to $45.25 \AA$ while from about $4{ }^{\circ} \mathrm{C}$ to $18{ }^{\circ} \mathrm{C}$, the period of the $2 \mathrm{~L}_{2}$ phase increases until about $42.22 \AA$, meaning that a $2 \mathrm{~L}_{1} \alpha \rightarrow 2 \mathrm{~L}_{2}$ $\beta$ ' transition is possible in this temperature T range.

\subsubsection{Intensity evolution}

The evolutions of the maximal intensities of the XRD peaks recorded at small angles are plotted in Figure 10A together with delimitations of these evolutions. First, the sharp decrease in intensity of the diffraction peaks associated with the $4 \mathrm{~L} \beta$, $(84.5 \AA)$ in the range $-6{ }^{\circ} \mathrm{C}<\mathrm{T}<3{ }^{\circ} \mathrm{C}$ corresponds to the decrease in intensity of the $2 \mathrm{~L}_{2}$ while in this same interval of temperature the intensity of $2 \mathrm{~L}_{1}$ is practically constant. We call this process $\mathrm{P} 1$. In the range $3{ }^{\circ} \mathrm{C}<\mathrm{T}<19{ }^{\circ} \mathrm{C}$, a decrease in intensity of the $2 \mathrm{~L}_{1}(47.6 \AA)$ which is analyzed as the melting of this variety is correlated with a significant increase in the intensity of the line $2 \mathrm{~L}_{2}$. Likely some TG originating from the $2 \mathrm{~L}_{1}$ organization incorporate the $2 \mathrm{~L}_{2}$ variety. We call this second process $\mathrm{P} 2$. This increase is followed by its progressive melting from $19^{\circ} \mathrm{C}$ to $42.5^{\circ} \mathrm{C}$.

\subsubsection{Thermal analysis}

The DSC curve recorded simultaneously with XRDT experiments is presented in Figure 10B. Again the coupling of XRDT and DSC techniques on the same sample allows the relating of its structural and thermal behavior as a function of the temperature. On the melting curve recorded, the different $T$ ranges observed can be analyzed as follows.

The first increase in the endothermic signal is attributed in fact to the superimposition on the progressive melting process observed previously at slower crystallization rates, of an exothermic event recorded between about -6 and $3{ }^{\circ} \mathrm{C}$. This event corresponds to process $\mathrm{P} 1$ above and is related to the melting of the $4 \mathrm{~L}$ structure. In the range $3{ }^{\circ} \mathrm{C}<\mathrm{T}<19^{\circ} \mathrm{C}$, a second exotherm superimposes on the progressive melting of the $2 \mathrm{~L}_{1} \alpha$ structure. Finally, the endothermic large peak recorded is related to the melting of the $2 \mathrm{~L}_{2} \beta^{\prime}$ 'structure until final melting of all ADMF TG over $42.5^{\circ} \mathrm{C}$. The last process, $\mathrm{P} 2$, has been analyzed above as a $\alpha \rightarrow \beta$ ' transition with liquid state as an intermediate affecting part of the TG. The first process, $\mathrm{P} 1$, is more complex to interpret. The tentative interpretation that fits all observations is that the line observed at $84.5 \AA$ is in fact the first order of a 4L structure; the $2 \mathrm{~L}$ period at $42.15 \AA$ may correspond to both the superimposition of the second order of the $4 \mathrm{~L}$ structure and the $\beta, 2 \mathrm{~L}_{2}$ structure which melts at higher temperatures. This $4 \mathrm{~L}$ phase, which only exists at fast cooling rates and at low temperatures, disappears via an exothermic process in the $-6{ }^{\circ} \mathrm{C}<\mathrm{T}<3{ }^{\circ} \mathrm{C}$ range, and corresponds to the formation of periodic defects in the longitudinal packing that gives birth to the line at $84.5 \AA$. These defects and the line disappear upon heating by molecular rearrangement 


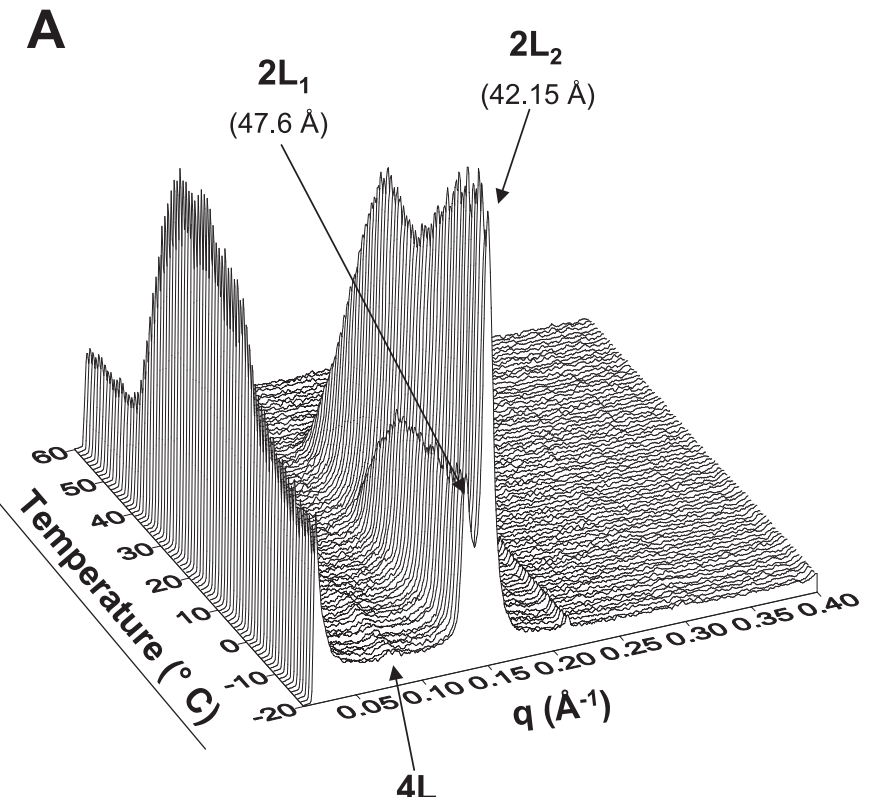

$(84.5 \AA)$

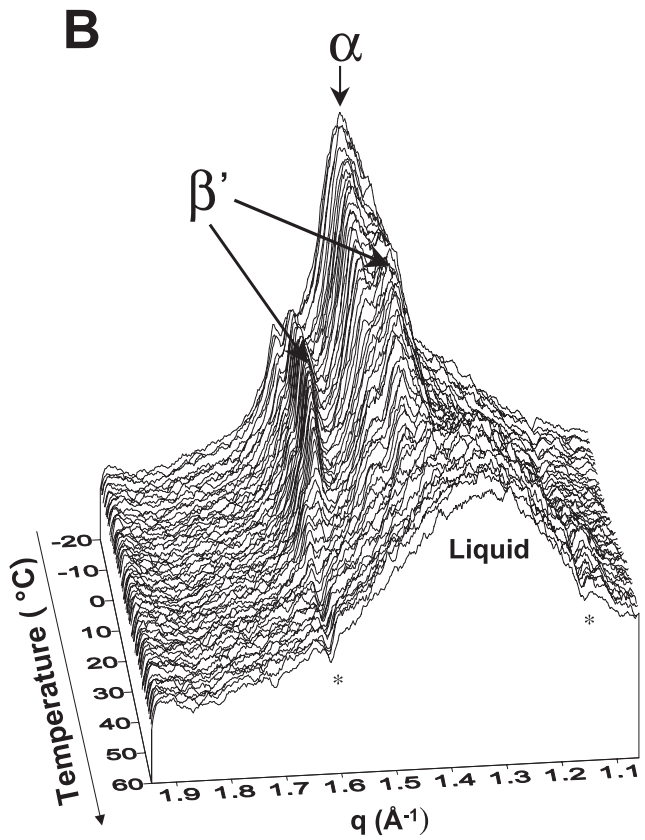

Figure 8. Three-dimensional plots of small- $(\mathbf{A})$ and wide- $(\mathbf{B})$ angle X-ray diffraction patterns recorded as a function of time during heating of anhydrous dromedary milk fat at $1{ }^{\circ} \mathrm{C} \cdot \mathrm{min}^{-1}$ after cooling at $5{ }^{\circ} \mathrm{C} \cdot \mathrm{min}^{-1}(*$ asterisk symbol corresponds to negative peak due to the wide-angle detector defects). The crystalline structures identified are noted in the figure. 

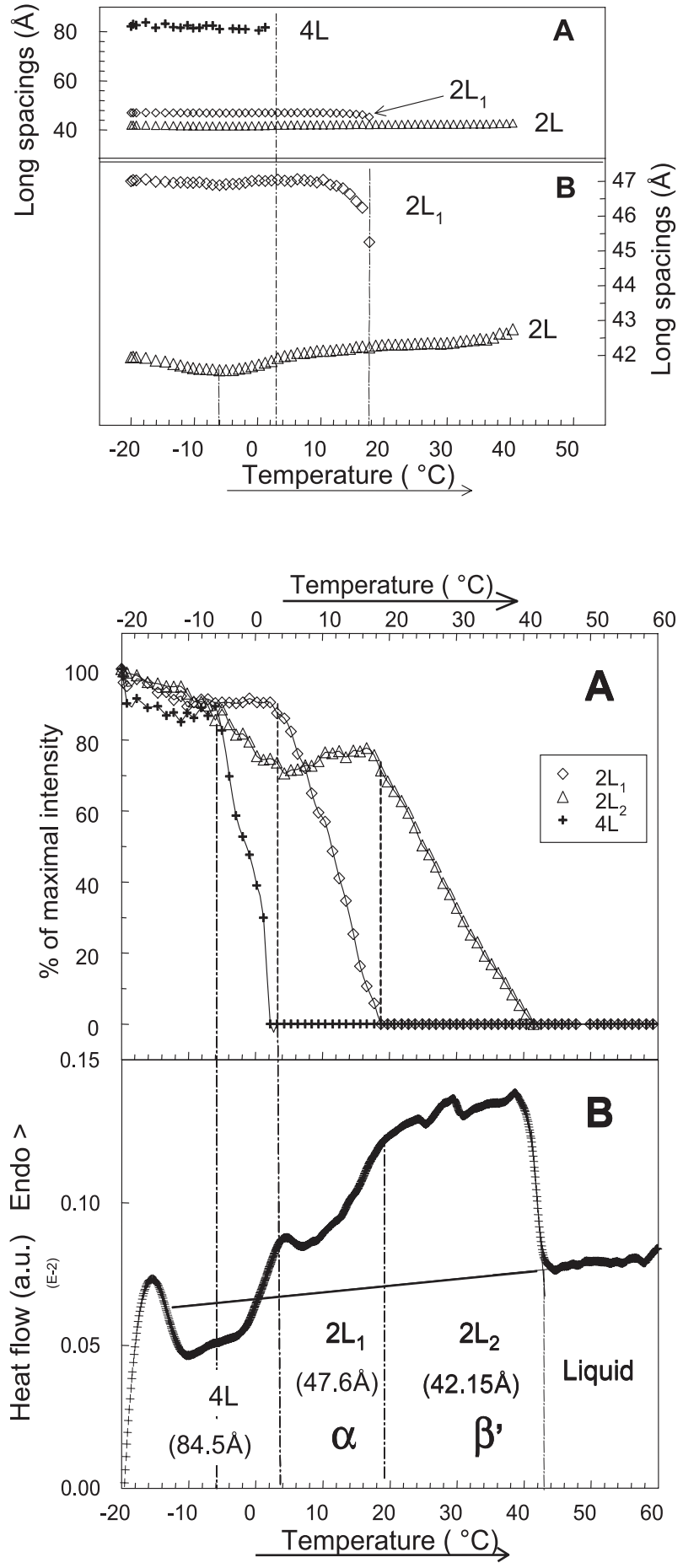

Figure 9. Evolution of the (A, B: different scales) long spacings of anhydrous dromedary milk fat crystals shown in Figure 8 during heating at $1{ }^{\circ} \mathrm{C} \cdot \mathrm{min}^{-1}$. The vertical dashed lines delimit $\mathrm{T}$ ranges of intensity and spacing evolutions.
Figure 10. Evolution of the maximal intensities of the diffraction peaks recorded in Figure $8(100 \%$ corresponds to the strongest peak). (A) Evolution of the long spacings. (B) DSC melting curve recorded simultaneously to XRD experiments during heating of anhydrous dromedary milk fat at $1^{\circ} \mathrm{C} \cdot \mathrm{min}^{-1}$, following cooling at $5^{\circ} \mathrm{C} \cdot \mathrm{min}^{-1}$. The vertical dashed lines delimit $\mathrm{T}$ ranges of intensity and spacing evolutions. 
Table I. Summary of the structural and thermal characteristics of anhydrous dromedary milk fat observed by XRDT and DSC after cooling at different rates and melting at $1{ }^{\circ} \mathrm{C} \cdot \mathrm{min}^{-1}$.

\begin{tabular}{|c|c|c|c|c|c|c|}
\hline \multirow{2}{*}{$\begin{array}{l}\text { Cooling } \\
\text { rate } \\
\left({ }^{\circ} \mathrm{C} \cdot \mathrm{min}^{-1}\right)\end{array}$} & \multirow{2}{*}{$\begin{array}{c}\text { Number of } \\
\text { crystallization } \\
\text { peaks }\end{array}$} & \multirow{2}{*}{$\begin{array}{c}\text { Initial } \\
\text { temperature of } \\
\text { crystallization } \\
\left({ }^{\circ} \mathrm{C}\right)\end{array}$} & \multirow{2}{*}{$\begin{array}{c}\text { Final melting } \\
\text { temperature } \\
\left({ }^{\circ} \mathrm{C}\right)\end{array}$} & \multicolumn{2}{|c|}{$\begin{array}{l}\text { Varieties observed } \\
\text { upon cooling }\end{array}$} & \multirow{2}{*}{$\begin{array}{l}\text { Thermal beha- } \\
\text { vior upon } \\
\text { - heating } \\
\text { (chain packing) }\end{array}$} \\
\hline & & & & Chain packing & $\begin{array}{l}\text { Molecule } \\
\text { stacking }\end{array}$ & \\
\hline 0.1 & 2 & 32 & 45.6 & $\beta^{\prime}$ & $2 \mathrm{~L}(42.15 \AA)$ & Only $\beta^{\prime}$ melts \\
\hline 1 & 3 & $\begin{array}{c}24 \\
20 \\
4\end{array}$ & 42.5 & $\alpha$ then $\beta$, & $\begin{array}{c}2 \mathrm{~L}_{1}(46.5 \AA) \\
2 \mathrm{~L}_{2}(42.15 \AA)\end{array}$ & $\begin{array}{l}\alpha \text { melts first } \\
\text { then } \beta\end{array}$ \\
\hline 5 & 2 & $\begin{array}{c}19.5 \\
6\end{array}$ & 43 & $\alpha$ then $\beta$, & $\begin{array}{l}2 \mathrm{~L}_{1}(47.6 \AA) \\
2 \mathrm{~L}_{2}(42.15 \AA) \\
+4 \mathrm{~L}(84.5 \AA)\end{array}$ & $\begin{array}{c}\beta^{\prime} 4 \mathrm{~L} \rightarrow \beta^{\prime} 2 \mathrm{~L} \\
\text { and } \alpha \rightarrow \beta^{\prime} \\
\text { transition } \\
\text { then } \beta^{\prime} \text { melts }\end{array}$ \\
\hline
\end{tabular}

or simply do not manifest when the cooling rate is slow enough to allow the correct packing of molecules in a $2 \mathrm{~L}$ structure.

\subsection{Influence of the rate of cooling on the thermal and structural properties of ADMF}

\subsubsection{Thermal behavior}

The thermal behavior of ADMF was studied by the coupled XRDT / DSC techniques at different cooling rates $\left[0.1^{\circ} \mathrm{C} \cdot \mathrm{min}^{-1}\right.$ (Fig. $3 \mathrm{C}$ in [9]), $1^{\circ} \mathrm{C} \cdot \mathrm{min}^{-1}$ (Fig. 3C) and $5^{\circ} \mathrm{C} \cdot \mathrm{min}^{-1}$ (Fig. 7B)].

Following crystallization, all the samples of $\mathrm{ADMF}$ were heated at the same rate of $1^{\circ} \mathrm{C} \cdot \mathrm{min}^{-1}$, in order to study the influence of the cooling rate $\left(0.1,1\right.$ and $\left.5^{\circ} \mathrm{C} \cdot \mathrm{min}^{-1}\right)$ on the melting behavior of ADMF TG (Fig. 7C in [9], Fig. 5 and Fig. 7B, respectively).

DSC recordings show that the shape of both the crystallization and melting curves depends on the cooling rate. Table I summarizes the different thermal properties of the ADMF after cooling at different rates and its subsequent melting at $1{ }^{\circ} \mathrm{C} \cdot \mathrm{min}^{-1}$. This table shows that:

(i) The initial temperature of crystallization of ADMF decreases with increasing cooling rate, in relation to the nucleation process [29]. (ii) At an intermediate rate, upon cooling at $1{ }^{\circ} \mathrm{C} \cdot \mathrm{min}^{-1}$, our results show the existence of three exotherms, while only two exotherms have been observed upon cooling of the ADMF at $5{ }^{\circ} \mathrm{C} \cdot \mathrm{min}^{-1}$ and at $0.1^{\circ} \mathrm{C} \cdot \mathrm{min}^{-1}$.

(iii) The apparent simplicity of the DSC crystallization curve (only two well-resolved exotherms are observed upon cooling at $5{ }^{\circ} \mathrm{C} \cdot \mathrm{min}^{-1}$ ) contrasts with the complexity of the melting recording which shows at least three endotherms.

(iv) At $\mathrm{T}<10{ }^{\circ} \mathrm{C}$, the DSC curve recorded upon heating after the fast cooling at $5{ }^{\circ} \mathrm{C} \cdot \mathrm{min}^{-1}$ likely results from overlapping of at least one exotherm and several endotherms resulting from the reorganization of different types of TG (if one considers the length and the insaturation of FA chains) in different crystal types favored by the presence of an intermediate liquid phase in relation to the monotropic behavior of the TG. Such behavior was only analyzed in detail in the light of coupled DSC and XRDT experiments.

(v) The melting curves recorded at $1{ }^{\circ} \mathrm{C} \cdot \mathrm{min}^{-1}$ after the cooling of ADMF at the different cooling rates correspond to several exotherms and endotherms overlapping each other. For the subsequent heating that followed cooling of the ADMF at $1^{\circ} \mathrm{C} \cdot \mathrm{min}^{-1}$ and $5^{\circ} \mathrm{C} \cdot \mathrm{min}^{-1}$, we distinguished different $\mathrm{T}$ ranges. The $\mathrm{T}$ ranges 

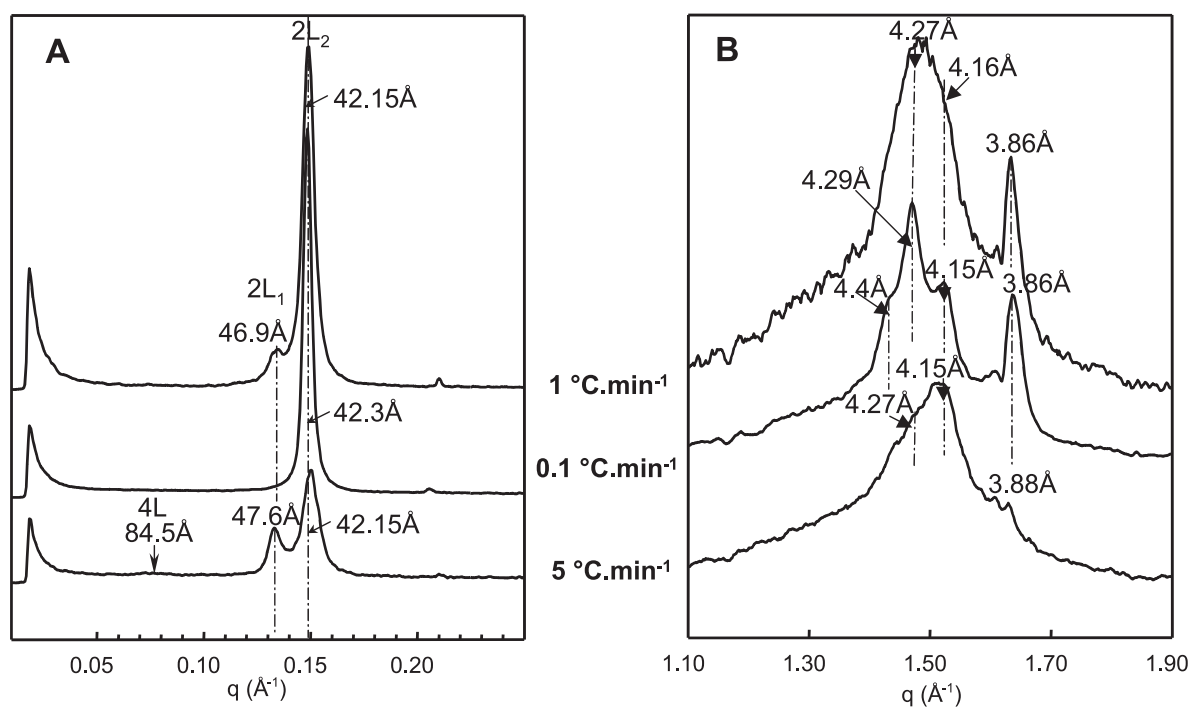

Figure 11. XRD patterns recorded at $-20^{\circ} \mathrm{C}$ at $(\mathbf{A})$ small and $(\mathbf{B})$ wide angles after different cooling of anhydrous dromedary milk fat at different rates as indicated in the figure.

observed do not correspond to that of ABMF identified as the melting of, respectively: the low melting point (LMP), medium melting point (MMP) and high melting point (HMP) fractions. Moreover, the melting curves of ABMF show three much separated endotherms corresponding to the melting of fractions cited above [21]. These authors found that the heating of $\mathrm{ABMF}$ at $2{ }^{\circ} \mathrm{C} \cdot \mathrm{min}^{-1}$ after cooling at different rates $\left(-0.5,-1,-2,-3\right.$ and $\left.-5{ }^{\circ} \mathrm{C} \cdot \mathrm{min}^{-1}\right)$ showed a first endotherm (LMP fraction) that ends toward $11^{\circ} \mathrm{C}$, a second one (MMP fraction), quite sharp, beginning at this temperature and spreading until $18^{\circ} \mathrm{C}$ and finally, a last one (HMP fraction), which is the largest observed until the completion of the melting of the HPF fraction of TG (about $36.5^{\circ} \mathrm{C}$ ).

\subsubsection{Structural behavior}

Figure 11 represents, respectively the small- (Fig. 11A) and wide- (Fig. 11B) angle XRD patterns recorded at $-20{ }^{\circ} \mathrm{C}$ after cooling ADMF at different rates: 0.1 , 1 and $5{ }^{\circ} \mathrm{C} \cdot \mathrm{min}^{-1}$.
The small-angle XRD peak width at half maximum height of the line corresponding to the same main $2 \mathrm{~L}$ structure is directly related to the rate of cooling. The faster the rate, the larger the line width (Fig. 11A). It means that structures generated by the slow cooling are well organized compared with those formed during a cooling at intermediate $\left(1{ }^{\circ} \mathrm{C} \cdot \mathrm{min}^{-1}\right)$ and fast $\left(5^{\circ} \mathrm{C} \cdot \mathrm{min}^{-1}\right)$ rates. This further correlates the above interpretation of the origin of the line at $84.5 \AA$.

Cooling of ADMF in fast conditions $\left(5^{\circ} \mathrm{C} \cdot \mathrm{min}^{-1}\right)$, or at an intermediate cooling rate $\left(1^{\circ} \mathrm{C} \cdot \mathrm{min}^{-1}\right)$, first leads to the crystallization of the $\alpha$ form with the existence of longitudinal stacking of the TG molecules corresponding to double-chain length structures (47.6 $\AA$ and $46.9 \AA$, respectively, likely the same structure with slightly different TG compositions) (Fig. 11A). This lateral organization of fatty acid chains in a hexagonal cell has not been observed upon slow cooling at $0.1{ }^{\circ} \mathrm{C} \cdot \mathrm{min}^{-1}$ that directly generates the stable form (2L $\left.\beta^{\prime}\right)(42.15 \AA)$ (Fig. 11A). 
This unstable crystalline form $\alpha$ is responsible for the occurrence of a line at $4.16 \AA$ at wide angles on the plot recorded upon cooling at $1{ }^{\circ} \mathrm{C} \cdot \mathrm{min}^{-1}$ and the observation of a $4.15 \AA$ line on the plot recorded upon cooling at $1{ }^{\circ} \mathrm{C} \cdot \mathrm{min}^{-1}$ (Fig. 11B). This small distance was absent on the plot recorded upon cooling at $0.1{ }^{\circ} \mathrm{C} \cdot \mathrm{min}^{-1}$ at wide angles. Indeed, there are only those that correspond to a stable form $\beta$ ' (3.86 $\AA$, $4.15 \AA, 4.29 \AA$ and $4.4 \AA$ ) (Fig. 11B). At this cooling rate, the ADMF does not seem to be able to crystallize under a $\beta$ form (which is the alternate case for fats not crystallizing under a $\beta$ ' form [22]) probably because of its complex and heterogeneous TG composition that makes difficult the adoption of a compact structure like that of a $\beta$ form.

It is important to say that the cooling rate is a key factor. Indeed, it frequently determines the size and the nature of crystals [22]. If the cooling is fast, many crystals of small size appear and form a dispersed mass micro-crystalline. On the other hand, a slow cooling advantages the formation of large stable crystals (of $\beta$ ' form) likely of spherulitic shape. Concerning the influence of the cooling rate on the nature of crystals formed, observations made by polarized light microscopy are providing information on the $\mu \mathrm{m}$ scale which is complementary to that given on the molecular scale by the techniques used in this study.

Concerning the possible molecular packing within the unit cell of the different polymorphic forms reported above, Figure 12 summarizes some possible models of arrangement that might explain the X-ray data observed, especially the presence of a line at about $\mathrm{q}=0.08 \AA^{-1}(84.5 \AA)$. For these models, it was hypothesized that the occurrence of this line is related to defects in the $c$ direction rather than in the a or b directions because of the relationship $(\times 2)$ between the periods observed (42.2 and 84.5 $\AA$ ). For instance, the existence of a rippled phase as observed for pure phospholipids has been ruled out. However, it was not possible to decide which model fits the data better, taking into account both the labile character of this variety and the weakness of the firstorder line. Likely, existence of defects in

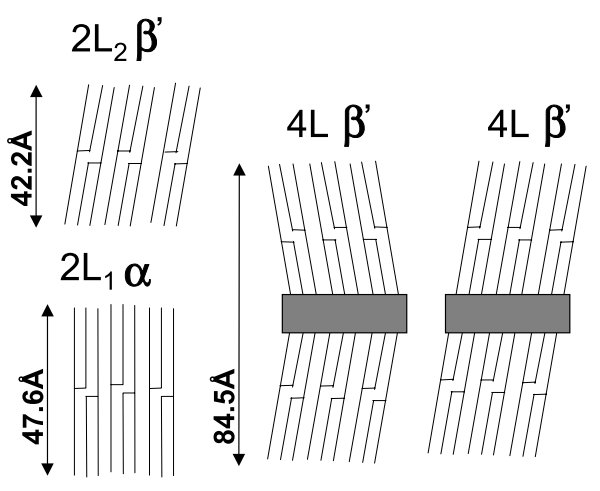

Figure 12. Possible stackings of triglyceride molecules in the crystalline forms discussed above. Angle of tilt of chains in the $\beta$ ' forms is about $27.7^{\circ}$ assuming that the $\alpha$ form is untilted $\left(0^{\circ}\right)$. Greyed zone corresponds to end of chain packing disorder.

the longitudinal organization of TG affects only part of the $\beta$ ' form, meaning that not all crystal parts are affected. The possibly that these defects are distributed more or less regularly in space, similarly to the spatial distribution of coexisting eutectic phases, cannot be ruled out [23].

\section{CONCLUSION}

The study of the thermal and structural behavior of natural fats is of importance regarding their functionality and their consequences on rheological properties of foods.

Regarding the techniques employed, we have shown in this paper and in the previous one that such studies could be carried out using simultaneous time-resolved synchrotron X-Ray Diffraction as a function of Temperature (XRDT) and high sensitivity Differential Scanning Calorimetry (DSC) techniques coupled together in the same apparatus and providing measurements from the same sample of ADMF. Such a combination of techniques allowed us to delimit the T ranges of existence of the crystalline structures formed by TG of ADMF, 
which is not directly possible from DSC recordings. Regarding the main results, several lamellar structures, 4L $(84.5 \AA)$ and $2 \mathrm{~L}$ (42.15-46.9 $\AA$ ), corresponding to $\alpha$ and $\beta$ ' polymorphs, were observed and characterized, as well as the transitions between them. The detection of a new crystalline form of 4L type, upon cooling of ADMF at a fast cooling rate, is very interesting as well as its transformation into $2 \mathrm{~L}$ species. The progressive melting of the $\beta$ ' form over a temperature range of about $50{ }^{\circ} \mathrm{C}$ is still puzzling and deserves to be analyzed in the future with the help of TG chemical analysis of the fractions as a function of temperature.

Acknowledgements: The authors thank Prof. H. Attia (ENIS, Sfax, Tunisia) for pertinent advice and stimulating our interest in camel's milk fat. T. Khorchani (ARI, Medenine, Tunisia) is also acknowledged for providing dromedary milk.

\section{REFERENCES}

[1] Abu-Lehia I.H., Physical and chemical characteristics of camel milk fat and its fractions, Food Chem. 34 (1989) 261-271.

[2] Attia H., Kherouatou N., Fakhfakh N., Khorchani T., Trigui N., Dromedary milk fat: biochemical, microscopic and rheological characteristics, J. Food Lipids 7 (2000) 95-112.

[3] Bayoumi S., Studies on composition and rennet coagulation of camel milk, Kieler Milchwirtsch. Forschungsber. 42 (1990) 3-8.

[4] Blanton T.N., Barnes C.L., Lelental M., Preparation of silver behenate coatings to provide low- to mid-angle diffraction calibration, J. Appl. Cryst. 33 (2000) 172-173.

[5] Cardak A.D., Yestismeyen A., Bruckner H., Quantitative comparaison of camel, goat and cow milk fatty acids, Milchwissenschaft 58 (2003) 127-130.

[6] Deffense E., Milk fat fractionation today: A review, J. Amer. Oil Chem. Soc. 70 (1993) 1193-1201.

[7] Farah Z., Streiff T., Bachmann M.R., Manufacture and characterization of camel milk butter, Milchwissenschaft 44 (1989) 412414

[8] Gorban M.S., Izzeldin M., fatty acids and lipids of camel milk and colostrum, Int. J. Food Sci. Nutr. 52 (2001) 283-287.
[9] Karray N., Lopez C., Lesieur P., Ollivon M., Dromedary milk fat: Thermal and structural properties 1 . Crystalline forms obtained by slow cooling, Lait 84 (2004) 399-416.

[10] Keller G., Lavigne F., Forte L., Andrieux K., Dahim M., Loisel C., Ollivon M., Bourgaux C., Lesieur P., DSC and X-Ray diffraction coupling specifications and applications, J. Thermal Anal. 51 (1998) 783-791.

[11] Khan B.B., Iqbal A., Production and composition of camel milk. Review, Pak. J. Agric. Sci. 38 (3-4) (2001) 64-68.

[12] Knoess K.H., Le chameau producteur de viande et de lait, Rev. Mond. Zootech. 22 (1977) 39-44.

[13] Larsson K., On the structure of the liquid state of triglycerides, J. Amer. Oil Chem. Soc. 69 (1992) 835-836.

[14] Lopez C., Lesieur P., Keller G., Ollivon M., Thermal and structural behaviour of milk fat. 1. Unstable species of cream, J. Coll. Int. Sci. 229 (2000) 62-71.

[15] Lopez C., Lavigne F., Lesieur P., Bourgaux C., Ollivon M., Thermal and structural behaviour of milk fat. 1. Unstable species of anhydrous milk fat, J. Dairy Sci. 84 (2001) 756-766.

[16] Lopez C., Lavigne F., Lesieur P., Keller G., Ollivon M., Thermal and structural behaviour of anhydrous milk fat. 2. Crystalline forms obtained by slow cooling, J. Dairy Sci. 84 (2001) 2402-2412.

[17] Lopez C., Lesieur P., Bourgaux C., Keller G., Ollivon M., Thermal and structural behaviour of milk fat. 2. Crystalline forms obtained by slow cooling of cream, J. Coll. Int. Sci. 240 (2001) 150-161.

[18] Lopez C., Riaublanc A., Lesieur P., Bourgaux C., Keller G., Ollivon M., Definition of a model fat for crystallization-in-emulsion studies, J. Amer. Oil Chem. Soc. 78 (2001) 1233-1244.

[19] Lopez C., Bourgaux C., Lesieur P., Bernadou S., Keller G., Ollivon M., Thermal and structural behaviour of milk fat : 3. Influence of cooling rate and droplet size on cream crystallization, J. Coll. Int. Sci. 254 (2002) 64-78.

[20] Lopez C., Bourgaux C., Lesieur P., Ollivon M., Crystalline structures formed in cream and anhydrous milk fat at $4{ }^{\circ} \mathrm{C}$, Lait 82 (2002) 317-335.

[21] Lopez C., Lavigne F., Lesieur P., Ollivon M., Thermal and structural behaviour of anhydrous milk fat: 3 . Influence of cooling rate, J. Dairy Sci. 88 (2005) 511-526.

[22] Marangoni A.G., Fat crystal networks, Food Science and Technology Series volume 140, 
Marcel Dekker Inc., New York, USA (2005) $850 \mathrm{p}$.

[23] Ollivon M., Perron R., Propriétés physiques des corps gras, in : Karleskind A., Wolff J.P., Guttmann J.F. (Eds.), Manuel des corps gras, Lavoisier, Paris, France, 1992, pp. 433-442.

[24] Orlov V.K., Servetnik-Chalaya G.K., Some physical and chemical characteristics of fat and fatty acid composition of lipids of camel milk, Voprosy Pitaniya 5 (1981) 67-69.

[25] Sato K., Polymorphism of pure triacylglycerols and natural fats, in: Padley F.B. (Ed.), Advances in Applied Lipid Research, vol. 2, JAI Press, Ltd, London, UK, 1996, pp. 213268
[26] Sawaya W.N., Khalil J.K., Al-Shalhat A., AlMohammed H., Chemical composition and nutrition quality of camel milk, J. Food Sci. 49 (1984) 744-747.

[27] Timms R.E., The phase behaviour and polymorphism of milk fat, milk fat fractions, and fully hardness milk fat, J. Dairy Technol. 35 (1980) 47-53.

[28] Timms R.E., The phase behaviour of mixtures of cocoa butter and milk fat, Lebensm. Wiss. Technol. 13 (1980) 61-65.

[29] Walstra P., Jenness R., Dairy Chemistry and Physics, Wiley and Sons, New York, USA, 1984. 